\title{
ペルオキシダーゼの反応特性と漂白プロセス
}

\section{Reaction Characteristic and Bleaching Process of Peroxidase}

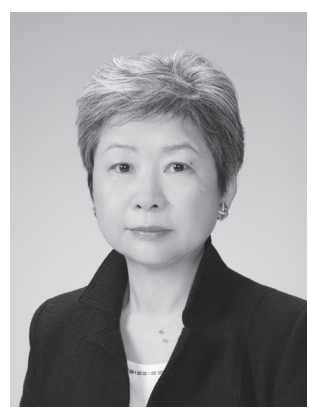

\author{
森田 みゆき \\ 北海道教育大学 \\ T 002-8501 \\ 札幌市北区あいの里 5-3-1
}

Miyuki MORITA

Hokkaido University of Education

5-3-1, Ainosato, Kita-ku, Sapporo, 002-8501, Japan

論文要旨:酸化還元酵素であるペルオキシダーゼを環境に配慮した繊維加工や洗浄配合剤へ利用するため, 熱耐性，溶媒への耐性， $\mathrm{pH}$ 特性，反応の活性化などを検討した。ペルオキシダーゼは，広い基質特異性を 有する。広い $\mathrm{pH}$ 範囲で種々の水素供与体と反応することがわかった。水素供与体との反応速度は, 水素供 与体の酸化電位によって影響を受けることがわかった。由来の異なるペルオキシダーゼは種々の耐性や反応 特性が異なることがわかった。モミガラ由来ペルオキシダーゼは, 熱耐性や有機溶媒耐性や過酸化水素耐性 に優れていることがわかった。ペルオキシダーゼの由来による耐性の違いや, 反応特性の違いを利用して, 利用目的に合わせて反応性をコントロールできることを明らかにした。西洋ワサビ由来ペルオキシダーゼと モミガラ由来ペルオキシダーゼを中心に反応機構についても述べる。

Abstract: The demand for environmentally friendly fiber processing and cleaning formulations prompted us to study the heat resistance, solvent resistance, $\mathrm{pH}$ characteristics, and the activation of peroxidases from various sources. Peroxidase has a broad substrate specificity. In a wide $\mathrm{pH}$ range, peroxidase was found to react with various hydrogen donor. The rate of reaction with hydrogen donors were found to be influenced by the oxidation potential of the hydrogen donor. Peroxidases from different sources were found to exhibit different stabilities and reaction characteristics. Rice full peroxidase showed excellent resistance towards heat, organic solvent, and hydrogen peroxide. The reaction mechanisms of horseradish peroxidase and rice full peroxidase were studied. Since the peroxidase reaction can be controlled by the reaction conditions, these conditions were proposed to suit the specific application.

Key words: peroxidase, reaction characteristic, decoloration

\section{1 はじめに}

繊維基質の漂白や, 繊維上に付着した有色物質の漂白 には，酸化剤や還元剤を用いて，酸化反応や還元反応に よる纎維上の有色物質を分解する方法が一般的であり， 反応機構も検討されている ${ }^{1,2)}$ 。衣類の多くは, 染料で 染色されており，それらの繊維に染着した染料を分解す ることなく，誤って着色した有色物質を漂白作用で分解 することも求められている。このような目的のため, 酸 化剂の中でも過炭酸ナトリウムや過ホウ酸ナトリウムは

連絡者：森田 みゆき

E-mail : morita.miyuki@s.hokkyodai.ac.jp
酸化反応が穏やかなため, 衣類用洗剂にも配合されてい る。

衣類に用いられている繊維は, 天然纎維の綿, 麻, 羊 毛, 絹を始めとして, 化学繊維のレーヨン, アセテート, ナイロン, ポリエステルなど, 多くの高分子物質である。 これらの分子の官能基の特徴により, 染料との結合の仕 方が異なるため, それぞれの繊維に対応した染料が開発 され, 利用されている。一時期には, 染料は 4,000 品種, 銘柄数は25,000 品目もあったが, 現在は若干減少して いる。

染色した衣服の色をそのままに維持し, 付着した有色 物質を分解したり, 洗濯時に衣類から離脱した染料で他 の衣類が色移りすることなく分解するのは, いかに繊維 
表面のみで反応を早く進行させるかということが課題と なる。

使用頻度の高い酸化漂白剂は, 高温, 強アルカリ条件 下では，反応が早く進行する。しかし，アルカリに耐性 のない䋊維, 綿用の反応染料には適しておらず, エネル ギーコストの問題もあった ${ }^{3)}$ 。

これらの課題の解決のため, 酸化還元酵素であるペル オキシダーゼ（POD）の反応の検討を行ってきた。本 論ではPOD を主に漂白剤として利用する場合の反応特 性について述べる。

\section{2 酸化還元酵素ペルオキシダーゼの反応性}

\section{$2 \cdot 1$ ペルオキシダーゼの特徵}

POD は, EC.1.11.1.7 に分類される過酸化水素を第一 基質として，第二基質である種々の水素供与体の酸化反 応を触媒する酸化還元酵素で, 動物, 植物, 菌類, バク テリアなどに広く分布している。PODは，活性部位に Fig. 1 に示すへム鉄を持ち, POD と水素供与体 $(\mathrm{AH})$ との酸化反応は次式の酵素サイクルで進行することが知 られている ${ }^{4)}$

POD $(+3)+\mathrm{H}_{2} \mathrm{O}_{2} \rightarrow$ Compound $\mathrm{I}(+5)+\mathrm{H}_{2} \mathrm{O}$

Compound $\mathrm{I}(+5)+\mathrm{AH} \rightarrow$ Compound II $(+4)+\mathrm{A}$

Compound II $(+4)+\mathrm{AH} \rightarrow \mathrm{POD}(+3)+\mathrm{A}$

なお，式中の（）の数字は活性部位のへム鉄の見か けの酸化数を示している。 nativeである POD (+3), およびこれらの中間体の Compound I , Compound II の状態で，へム鉄の吸収スペクトルは変化して，Fig. 2 に示すように soret 帯（またはB 帯）（400 nm 付近の極 めて強い吸収帯）と， Q 帯 $(480 \mathrm{~nm} \sim 650 \mathrm{~nm}$ に弱い吸 収帯）で固有のスペクトルとなる ${ }^{5)}$ 。

$\mathrm{POD}$ の中で, 西洋ワサビ由来 POD（HRP）は最も古

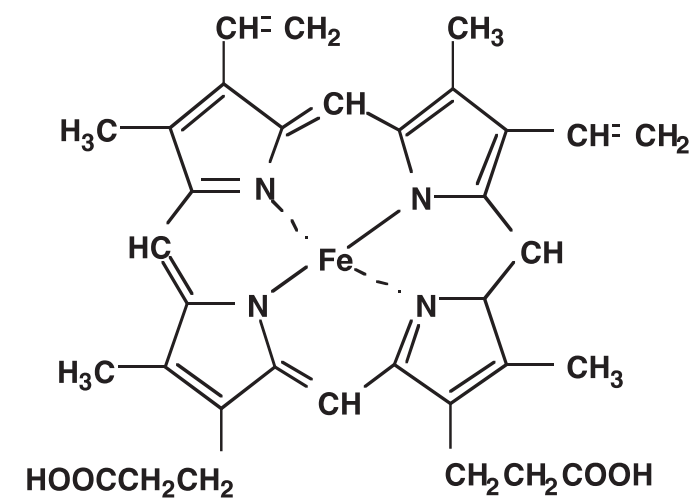

Fig. 1 Ferriprotoporphyrin (ferric heme) Activity site.

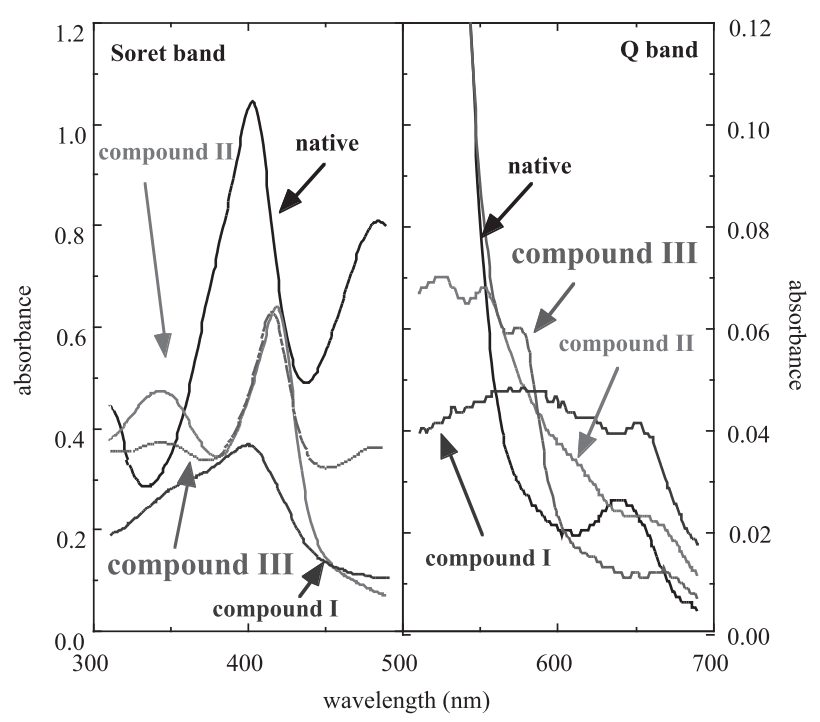

Fig. 2 Absorption spectra of POD.

くから知られており, 分子量は約 4 万で, モル吸光係数 は, $1.02 \times 10^{5} \mathrm{~mol}^{-1} \mathrm{dm}^{3} \mathrm{~cm}^{-1}(403 \mathrm{~nm})$ である ${ }^{6)}$ 。過酸 化物 (過酸化水素, 過酸化水素メチル, 過酸化水素エチ ル）に対する基質特異性は高いが，第二基質である水素 供与体に対する特異性は低いことが知られている。我々 は，水素供与体に対する特異性が低いことを利用して， 洗剤中の漂白剤として用いる可能性について検討を行っ た。

\section{$2 \cdot 2$ ペルオキシダーゼの反応特性}

上述のように, POD は分子内の活性部位に一個のへ ム鉄を有することから, PODのモル吸光係数から, POD のモル濃度を求めることができる。一般に酵素の 濃度は活性単位で示す事が多いが，ペルオキシダーゼは 基質特異性が低いことと，基質により反応速度が異なる ことから，POD 間，基質間の比較検討には，活性単位 を用いることは適さない。従って,ここに示す多くのデー 夕は，PODの濃度をモル濃度として同一濃度で検討し た結果を示している。

POD の反応は, 由来によって, また第二基質によって, $\mathrm{pH}$ の反応性は異なる。Fig. 3 に, HRP による Orange IIの退色反応におよぼす $\mathrm{pH}$ の影響を示している。緩衝 液により，反応速度は異なるが，pHの影響は同じ様な 傾向となる。第二基質が異なると, 反応速度が極大を示 す $\mathrm{pH}$ は異なる ${ }^{7)}$ 。第二基質として, Orange I, Orange II, Orange G などを比較すると, Fig. 4 に示す ように，同じ $\mathrm{pH}$ であっても，反応速度が異なる。これ は，それぞれの染料の酸化還元電位が異なるためで，酸 化還元電位の違いが, POD の酸化還元電位と差の大小 と関係するため, 酸化還元反応の進行のしやすさに影響 を与えると考えられる ${ }^{8)}$ 。また，PODを用いた退色反 


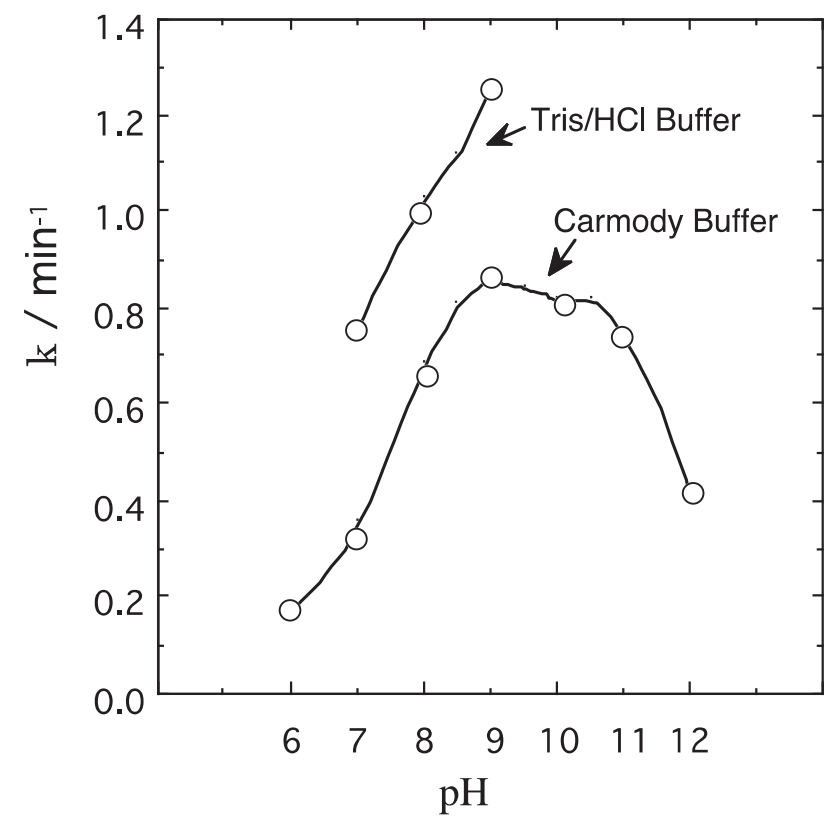

Fig. 3 Influence of $\mathrm{pH}$ on the decoloration rate constant of Orange II.

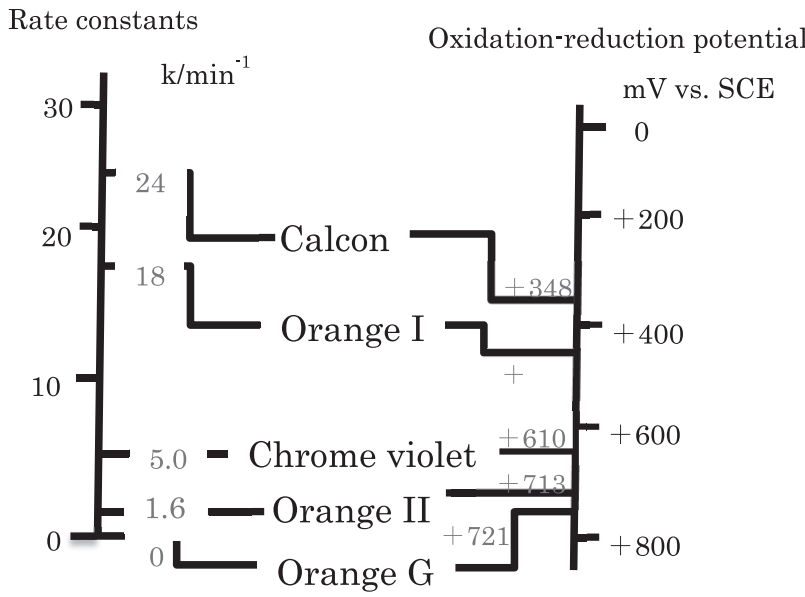

Fig. 4 Rate constant and oxidation-reduction potential of dye.

応は色素の分解に特異性を有し, POD の由来によって退 色速度や退色挙動が大きく異なることがわかっており ${ }^{9}$, 効率的な色素の退色反応には様々な要因が関与すること がわかっている。

\section{$2 \cdot 3$ 超酵素としてのペルオキシダーゼの可能性}

酵素は熱的に不安定であることが多く，熱的に安定で あることが要求される。Fig. 5 に 4 種の由来の異なる POD を用いた色素の退色反応に打ける反応温度の影響, Fig. 6 に $90^{\circ} \mathrm{C}$ で保存後に $80^{\circ} \mathrm{C}$ で反応した場合の退色曲 線を示した。反応温度の影響では，菌由来 POD (ARP) は， $50^{\circ} \mathrm{C}$ 以上で失活するが，植物を由来とするモミガラ 由来 $\mathrm{POD}(\mathrm{RPO})$, 大豆由来 $\mathrm{POD}(\mathrm{SPO})$, および HRP は高温になるほど反応速度は増大した。特に,

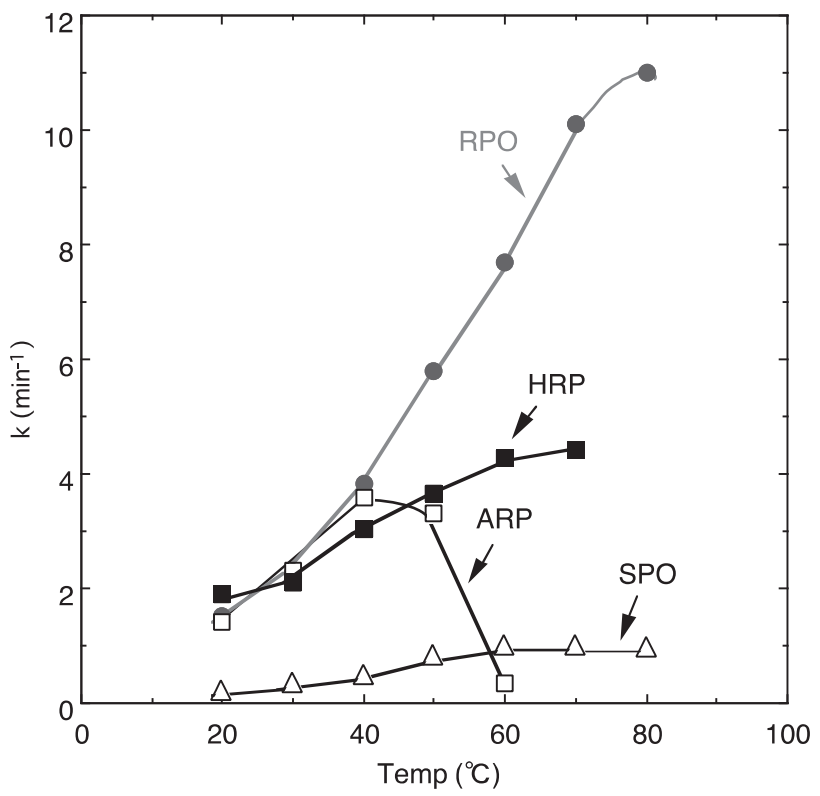

Fig. 5 Effect of reaction temperature on the decoloration rate constant of Orange II.

$\mathrm{RPO}$ の温度効果は著しい結果となった。高温で保存し た場合, HRP は保存時間で 5 分で退色速度は約 $1 / 2$ に なったが，RPOは 150 分保存後も，退色速度はほとん ど滅少しなかった。

一方，抗菌抢よび防臭などへの消費者の高い関心への 対応として，洗濯洗郕に酸素系漂白剤を配合したり，洗 浄槽に洗濯洗剂と共に酸素系漂白剂を添加して洗濯をす る方法を洗剤メーカーが推奨するなど，多様化してい る。従って, POD を洗濯時に漂白剤として使用するた めには，不活化せずに種々の濃度の $\mathrm{H}_{2} \mathrm{O}_{2}$ 条件下に扔い て，PODを用いた退色反応が安定に進行することは POD の実用化に必要不可欠と言える。

しかし, Arnaoらは, PODの反応で第一基質として 必要不可欠である $\mathrm{H}_{2} \mathrm{O}_{2}$ は, 高濃度条件下で POD の不 活化をもたらし反応の進行を妨げることを，HRPで明 らかにしている ${ }^{10)}$ 。そこで，我々は，4 種の由来の異な る POD を用いた色素の退色反応に打ける $\mathrm{H}_{2} \mathrm{O}_{2}$ 濃度の 影響や保存安定性などの $\mathrm{H}_{2} \mathrm{O}_{2}$ 耐性を調べた ${ }^{11)}$ 。Soret 带の最大吸収波長の経時変化を Fig. 7 に示した（RPO を用いた場合を(a)，HRPを用いた場合を（b))。 Compound III は, HRP の過剩な $\mathrm{H}_{2} \mathrm{O}_{2}$ 共存下において発 現し, 通常の反応サイクルと別経路をとるために HRP の反応阻害に起因することが確認されている ${ }^{10)}$ 。また, Compound IV は P-670 といわれ, 過剩の $\mathrm{H}_{2} \mathrm{O}_{2}$ 共存下や サリチル酸と $\mathrm{H}_{2} \mathrm{O}_{2}$ 共存下扔いて発現し ${ }^{12)}$, 酵素反応を 阻害することが確認され ${ }^{13)}$, さらに, Compound IIIの 破壞より，Compound IVが生成される反応連動性がある ことも明らかになっている ${ }^{14)}$ 。RPOは, Soret 带の最 

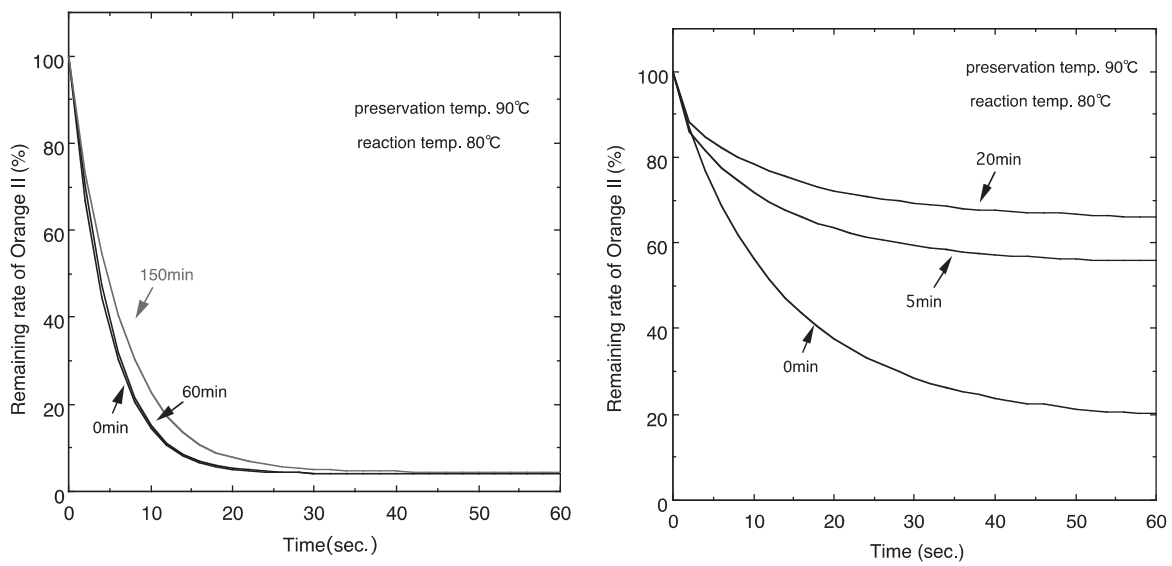

Fig. 6 Storage stability of the PODs at $90^{\circ} \mathrm{C}$. (Left : RPO, Right : HRP)
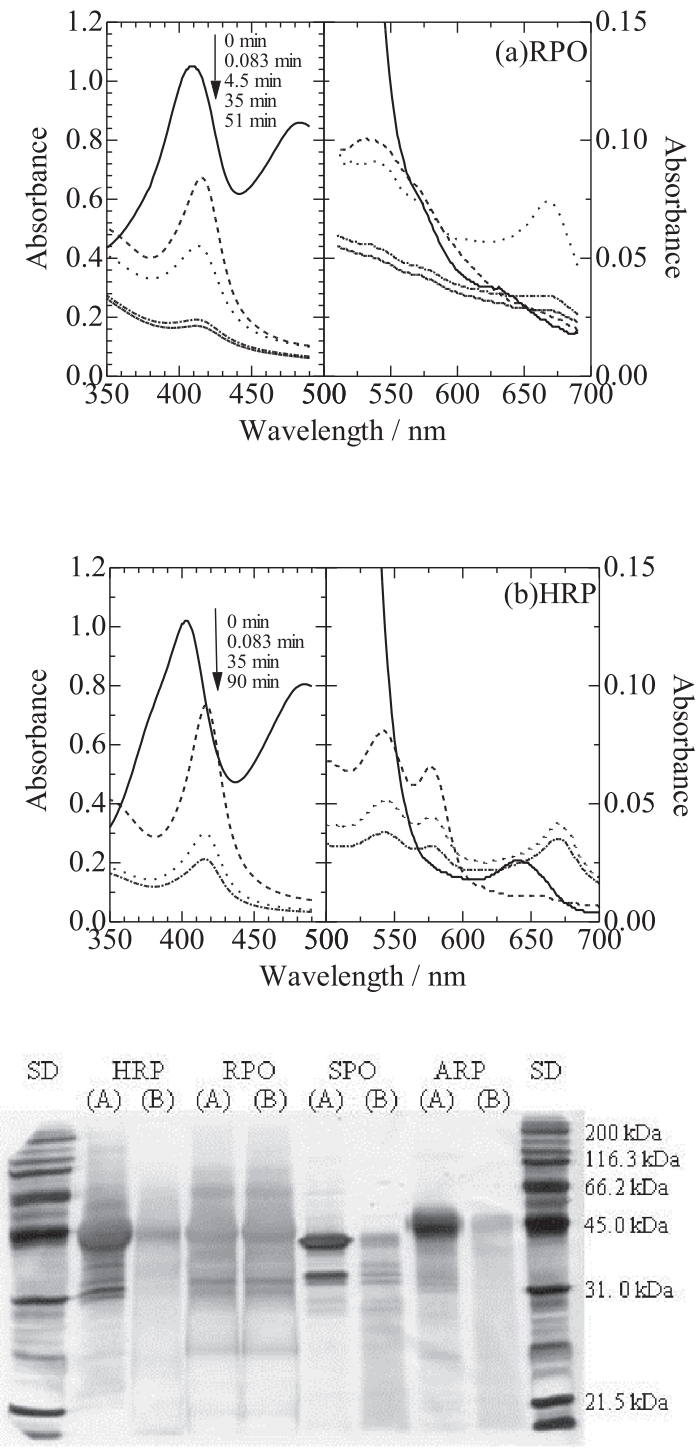

Fig. 7 Absorption spectra of POD. Fig. 7-a is RPO system, Fig.7-b is HRP system. Silver staining of SDS-PAGE of $12 \%$ gel electrophoresis product. The positions of molecular mass standards are indicated on the both sides (SD). (a); $\mathrm{H}_{2} \mathrm{O}_{2}$ concentration is $0.75 \mathrm{mM}$, (b) $\mathrm{H}_{2} \mathrm{O}_{2}$ concentration is $75 \mathrm{mM}$.

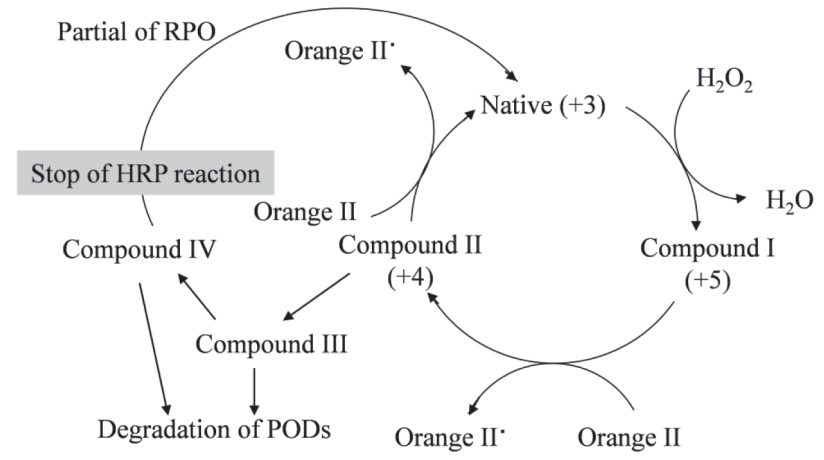

Fig. 8 Proposed mechanism for Orange II by RPO- $\mathrm{H}_{2} \mathrm{O}_{2}$ and HRP- $\mathrm{H}_{2} \mathrm{O}_{2}$ bleaching system in the high concentration of $\mathrm{H}_{2} \mathrm{O}_{2}$.

大吸収波長変化で示すように，418 nm に吸収を有する Compound IVの酸化状態から, 時間の経過とともに最大 吸収波長が短波長側に少しずつシフトし，一部分が native $(410 \mathrm{~nm})$ の状態に戻る。一方, HRPは, 反応 開始から 7 時間経過後も Compound III と Compound IVの 状態が継続し， nativeの状態に戻らなかった。また， SDS-PAGEにより各PODのタンパク質を解析した結果, $\mathrm{RPO}$ は $75 \mathrm{mM} \mathrm{H} \mathrm{H}_{2} \mathrm{O}_{2}$ の共存下においても $\mathrm{RPO}$ に由来す る約 $45 \mathrm{kDa}$ のバンド及びその他のバンド強度が低下し なかった。これらの結果から, 高濃度の $\mathrm{H}_{2} \mathrm{O}_{2}$ 共存下に おける反応スキームは，Fig. 8 のように進行すると考え られる。

さらに，POD を用いた色素の退色反応について，有 機溶媒耐性も調べた ${ }^{15)}$ 。用いた有機溶媒の種類によっ てオレンジIIの退色速度は異なり, HRP の酸化状態か ら, 水系と同様に退色速度が速いメタノール／水系では Compound IIIが発現しないことが確認された。一方，工 タノール，2-プロパノールを用いた場合，Compound III が発現し, Orange II の退色を阻害していることが明ら かになった。

POD の反応におけるこれらの耐性は, 由来により大 
きく異なることがわかった。中でも，RPOは，熱， $\mathrm{H}_{2} \mathrm{O}_{2}$, 有機溶媒の耐性に優れ, バイオマスとしての有 効利用も期待されていることから, 超酵素としての可能 性が大きいと考えられる。

\section{3 漂白剤としての応用}

実際の漂白剂としての応用のため, 色素の分解反応ス キームを検討した結果を, Fig. 9 に示す。Orange IIの 退色反応の反応過程を調べたところ, 水素供与体である Orange II の還元反応が終了しても, 反応溶液のスペク トルはしばらくCompound II のスペクトルであった。 さらに, HPLC, TLCなどによる検討の結果, Orange IIの退色反応は, Fig. 9 の右部分に示すように, Orange IIが，まず水素供与体として作用して生成した反応中間 体が, さらに次の POD サイクルで水素供与体として作 用していると考えられる ${ }^{16)}$ 。一方, 前述の由来の異な る PODによる反応速度の差異は, 各 PODの中間体と Orange II との反応速度 $\left(\mathrm{K}_{2}\right.$ と $\left.\mathrm{K}_{3}\right)$ の差によるものと 考えられる。

より効率的な漂白系, すなわち色素の退色速度が早く, かつ, どのような化学構造の色素も退色できる漂白系を 構築する必要がある。そこで, 色素の構造の退色反応へ の影響を調べたところ，色素により反応速度が大きく異 なることがわかった。そこで, いくつかのp-置換フエ
ノール誘導体は HRP とルミノールの化学発光反応にお

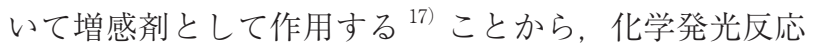
の活性化剂のうち Orange II と OrangeG の退色反応を行った ${ }^{18,19)} 。 p$-ヨー ドフェノールを用いた場合, 難分解性のオレンジ Gも 反応速度が $5.05 \mathrm{~min}^{-1}$ と大幅に増大したことから, 化学 発光反応における増感剤は, 色素の分解反応に対しても 活性化剤として有効であることがわかった。Fig. 10 に， 活性化剂共存と非共存による速度定数を示す。活性化剂 を共存させると，極大を示す $\mathrm{pH}$ はシフトする ${ }^{20)}$ 。これ は, POD と水素供与体間での酸化還元反応の進行のし やすさ, すなわち, 水素供与体の酸乘離定数が異なるた めと考えられる。

さらに, HRP-Orange II 反応系にグルコース - グルコー スオキシダーゼ（GOD）反応系をカップリングするこ とにより，グルコースと GOD との反応で生成する $\mathrm{H}_{2} \mathrm{O}_{2}$ を HRP-Orange II 反応系の酸化剂として供給する方法 ${ }^{21)}$ を検討した。 $\mathrm{pH}$ が増大するに伴い退色速度定数は増大 し, pH 8.5 から 9.0 の範囲で最大となった。退色反応の 最適条件では Orange II の移染防止に必要な退色速度 $(\mathrm{k}$ $\left.=2.0 \mathrm{~min}^{-1}\right)^{22)}$ が得られた。

POD に対して異なる反応速度を有する色素を共存し た場合, 反応液中の色素を分析した結果, Fig. 11 に示 すように, 先に水素供与体として作用した色素の反応中

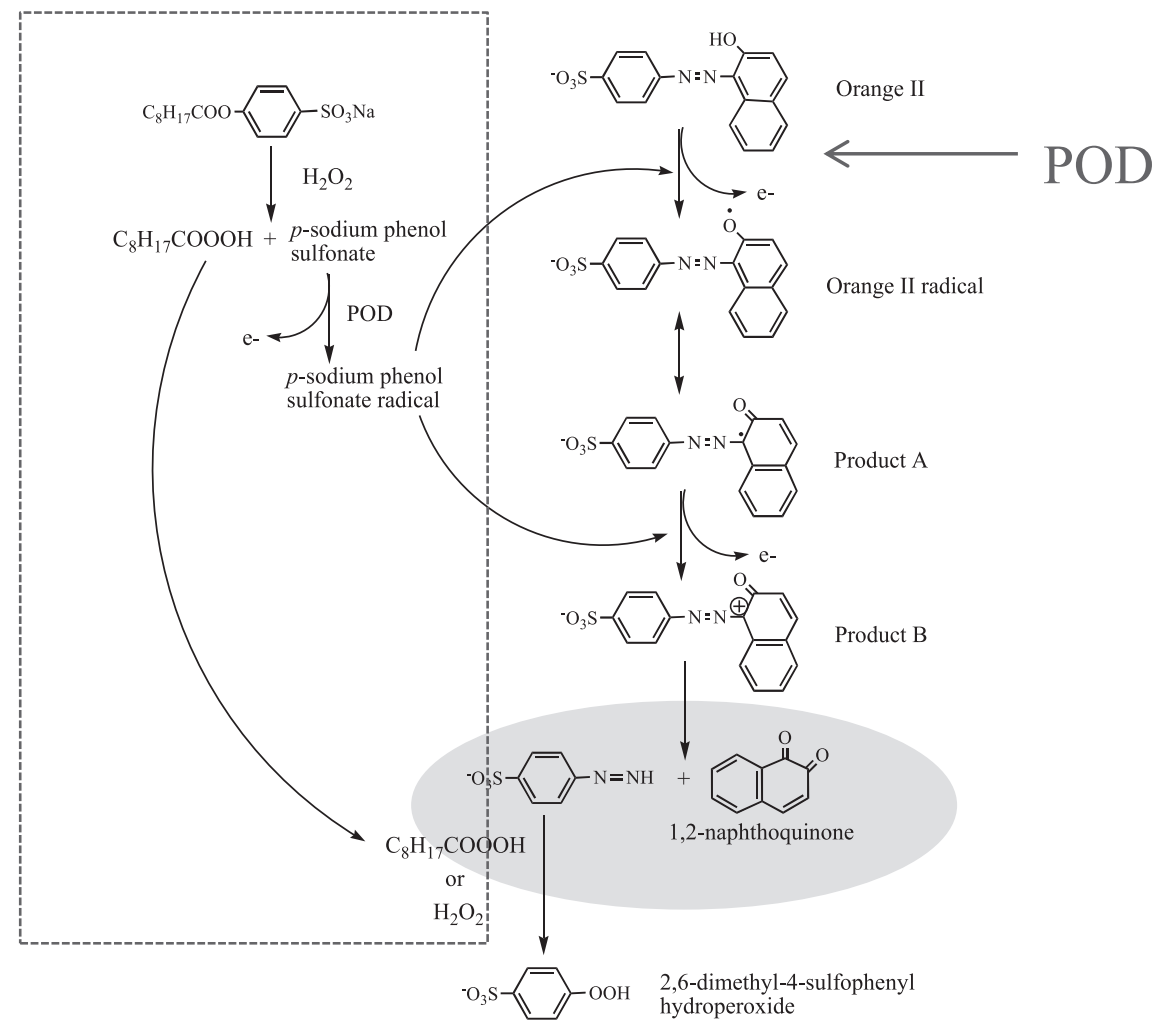

Fig. 9 Decomposition scheme of Orange II in the presence of organic peracid. 

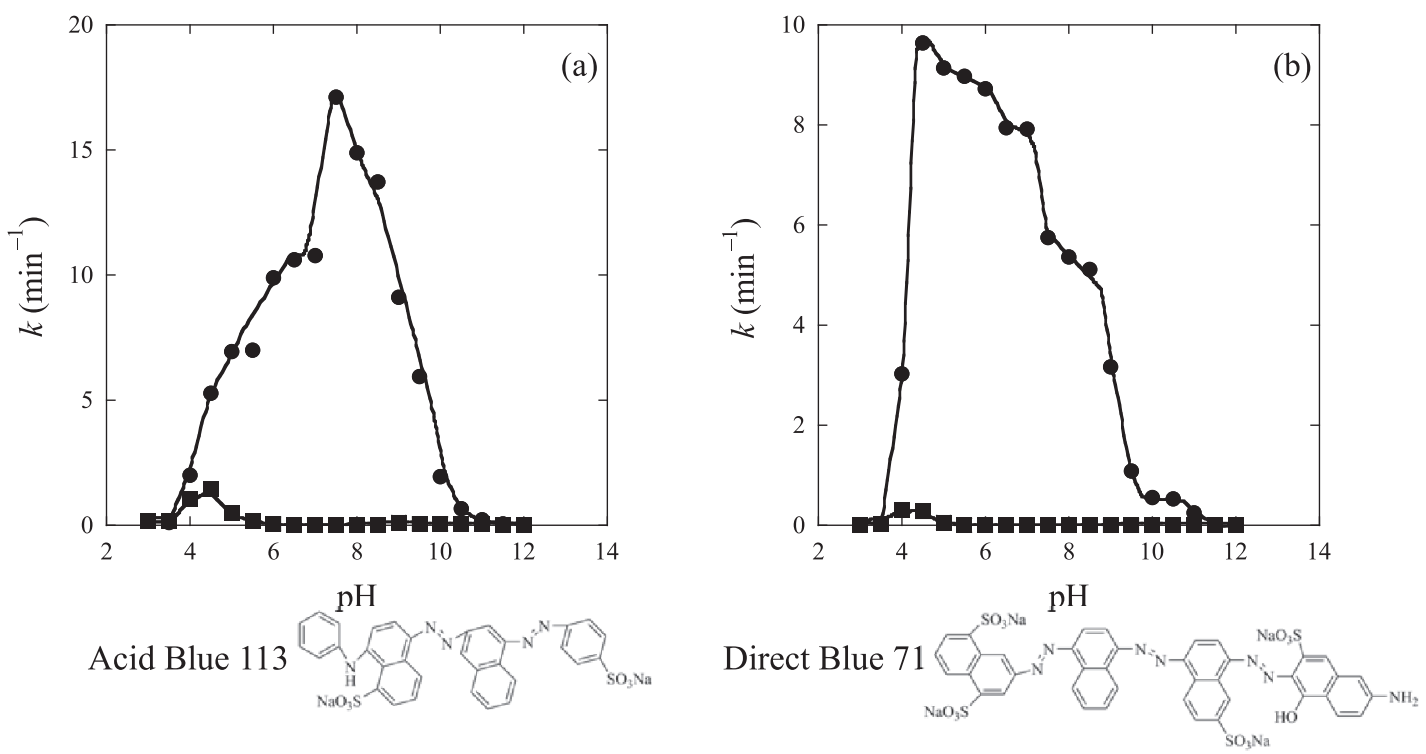

Fig. 10 Effect of activator on decolorization rate constant of Acid Blue 113 and Direct Blue 71.

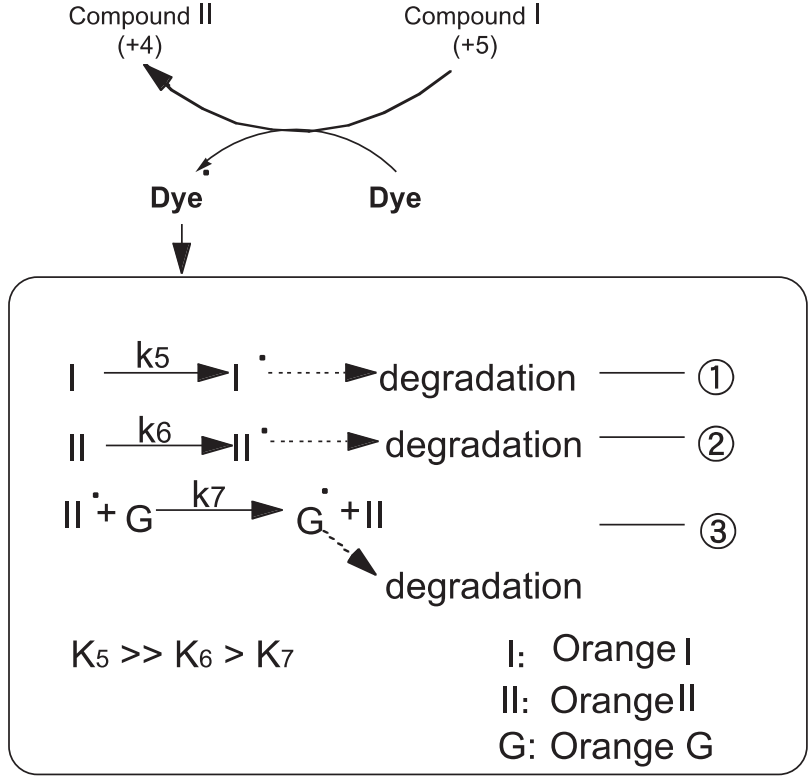

Fig. 11 Degradation reaction scheme of three mixing dyes on HRP system.

間体の色素のラジカルが水素供与体になりにくい色素 (難分解性色素) に作用して, 難分解性色素は単独で $\mathrm{POD}$ と反応するよりも, 反応速度が増大することがわ かった ${ }^{23)}$ 。

実用上，洗剤中の酸化漂白剤と共存することが考えら れる。酸化漂白剤は, 比較的穏やかな反応のため, 反応 の活性化のために漂白活性化剂を使用している場合が多 い。RPOに漂白活性化剤を共存させると, 反応速度が 増大することがわかった ${ }^{24)}$ 。その機構を, Fig. 9 の左の 枠部分に示す。漂白活性化剂 NOBS は $\mathrm{H}_{2} \mathrm{O}_{2}$ による分解 によって有機過酸, 及びp-フェノールスルホン酸ナト
リウムを生成する。生成されたか-フェノールスルホン 酸ナトリウムが RPO 系の活性化剂として作用し, RPO の中間体である Compound I, Compound II と反応し てp-フェノールスルホン酸ナトリウムのラジカルとな り，そのラジカルが Orange II とラジカル反応すること で, Orange II のラジカルはオレンジII と RO が直接 酸化還元反応する場合よりも速く形成されることがわ かった。

\section{4 おわりに}

近年では，家庭洗濯に新型の液体洗剂が使用されるよ うになり，家庭洗濯で使用される洗剤は多岐にわたって いる。しかし, 漂白剤の開発は今一歩遅れている感があ る。家庭洗濯用洗剤の液性は弱酸性から弱アルカリ性ま であり，特に液体洗剤で中性の普及が著しい。従来型の 漂白剂はアルカリ性での使用である。今回紹介した POD は，基質特異性が低いばかりでなく，活性化剤を 適宜選択することで，広い $\mathrm{pH}$ で安定的に使用できる可 能性がある。さらに, 環境負荷を考慮した新しいタイプ のドライクリーニングの検討が進むと予想されるが, 有 機溶媒耐性もある POD を使用する可能性もひろがるの ではないだろうか。

\section{文 献}

1) T. Tamura, T. Kubozono, M. Tamura \& H. Yoshimura, J. Jpn. Oil Chem. Soc., 44, 1086 (1995).

2) T. Tamura, T. Kubozono, M. Tamura \& H. Yoshimura, J. Jpn Oil Chem. Soc., 44, 1093 (1995).

3) Y. Imabayashi \& S. Yoshikawa, J. Jpn. Res. Assn. Textile End-Uses., 25, 400 (1992). 
4) H. B. Dunford, Adv. Inorg. Biochem., 4, 41 (1982).

5) K. Yokota \& I. Yamazaki, Biochem., 16, 1913 (1982).

6) B. B. Kimm, V. V. Pisarev \& A. M. Egorov, Anal. Biochem., 199, 1 (1991).

7) M. Morita, R. Ito, T. Kamidate \& H. Watanabe, Text. Res. J. 66, 470 (1996).

8）上舘民夫, 柴田剛典, 渡辺寛人, 森田みゆき, 日本油 化学会誌, 48, 497 (1999).

9) M. Morita, K. Takada, M. Morisaki \& E. Komatsu, Sení Gakkaishi, 64, 125 (2008).

10) M. B. Arnao, M. Acosta, J. A. del Río \& F. García-Cánovas, Biochemica Biophysica Acta, 1038, 85 (1990).

11）松林真奈美，松林誠，森田みゆき，繊維学会誌， 71, 250 (2015).

12) T. Kawano, S. Muto, M. Adachi, H. Hosoya \& F. Lapeyrie, Bios. Biotechnol. Biochem., 66, 646 (2002).

13) S. Bagger \& R. J. P. Williams, Acta Chem. Scand. 25, 976 (1971).

14) S. A. Adediran, Arch. Biochem. Biophys., 327, 279
(1996).

15) M. Morisaki, M. Morita \& K. Ito, J. Oleo Sci., 54, 573 (2005).

16）森田みゆき, 山口江利子, 小松恵美子, 伊藤理恵, 上 舘民夫, 渡辺寛人, 日本油化学会誌, 48, 793 （1999）.

17) F. G. Sanchez, A. N. Diaz \& J. A. G. Gracia, Anal. Chim. Acta., 310, 399 (1995).

18) M. Morita, T. Kamidate, T. Shibata \& H. Watanabe, J. Jpn. Oil Chem. Soc., 46, 807 (1997).

19）上舘民夫, 柴田剛典, 渡辺寛人, 森田みゆき, 日本油 化学会誌, 47, 1345 (1998).

20）東輝，森田みゆき，繊維学会誌，70，100（2014）.

21）森田みゆき, 小松恵美子, 上舘民夫, 渡辺寛人, 日本 油化学会誌, 46, 999 (1997).

22）森田みゆき，小松恵美子，上舘民夫，渡辺寛人，繊維 学会誌, 53, 289 (1997).

23）森田みゆき, 高田貴代美, 森崎真奈美, 小松恵美子, 繊維学会誌, 64, 125 (2008).

24）森田みゆき, 渡辺貴子, 東輝, 繊維学会誌, 69, 147 (2013). 